\title{
HUMAN LEPTOSPIROSIS: A TWENTY-NINE-YEAR SEROLOGICAL STUDY IN SÃO PAULO, BRAZIL
}

\author{
Eliete Caló ROMERO(1), Carla Cristiane da Motta BERNARDO(1) \& Paulo H. YASUDA(2)
}

\begin{abstract}
SUMMARY
A retrospective study of 9,335 cases of human leptospirosis in the state of São Paulo, Brazil, diagnosed between 1969 and 1997 showed that the disease is endemic throughout the state. Middle-aged adults, with a range of 20-39 years, were most frequently infected $(32.40 \%)$. The mean annual incidence was 0.53 per 100,000 population and the disease was more frequent in males $(87.0 \%)$. Cases occurred mainly in January to April each year. A peak was observed in 1991 and 1996 which rainfall average was 159.9 and 160.3, respectively. These data emphasize the potential public health importance of leptospirosis in the state of São Paulo, Brazil.
\end{abstract}

KEYWORDS: Human leptospirosis; Epidemiology; Serology; Brazil.

\section{INTRODUCTION}

Leptospirosis is a globally important zoonotic disease that affects humans on all continents, in both urban and rural contexts, and in temperate and tropical climes. Usually, human leptospirosis occurs after contact with water contaminated by urine of infected animals ${ }^{2}$. The number of infections increases in hot weather, usually in a rainy period ${ }^{4,5}$. Epidemics are possible in man in several conditions as rains, humid soil, or stagnant water. The clinical manifestations vary in terms of severity and symptomatology that makes the diagnosis of human leptospirosis difficult. The diagnosis of human leptospiral infection relies on either isolation of the causative organism from body fluids or the demonstration of a rise in specific serum antibodies ${ }^{2}$. This is important for effective therapy and epidemiological surveys.

Leptospirosis is endemic in Brazil, representing a human and veterinary health problem. In São Paulo, a state located in a southern region of Brazil, South America, with an estimated population of $36,966,527$ (148.57 inhabitants $\left./ \mathrm{km}^{2}\right)$, the human disease is observed mainly in urban areas ${ }^{4,5}$ and the rats are the main reservoirs of leptospires.

The purpose of this study was to report the incidence of leptospirosis from 1969 to 1997 to show the importance of human leptospirosis in the state of São Paulo and to describe some epidemiologic characteristics. Since there are no serological studies in São Paulo until 1968, our data emphasize the potential public health importance of leptospirosis in Brazil.

\section{MATERIALS AND METHODS}

Sera: Sera from patients with suspected leptospirosis from the whole state of São Paulo were regularly sent to Adolfo Lutz Institute. Between
1969 to 1997 , a total of 44,369 sera were analyzed. Of these, 33,380 were from the greater São Paulo area (capital of the state of São Paulo and 36 nearby municipalities). These sera were examined by the microagglutination test (MAT) according to World Health Organization ${ }^{2}$ using a battery of 20 live antigens representing the main pathogenic serogroups of Leptospira sp.

Diagnostic criteria and case classification: A case was defined as presumptive when a single sample showed a minimum titer of 1:200 or when two or more samples did not show a four-fold increase in titer. A case was defined as confirmed when two samples had a titer rise of $\geq 2$ dilutions between acute and convalescent samples ${ }^{2,3}$.

Leptospiral serogroup predominant was considered the titer which was the highest sample dilution with $50 \%$ of agglutination and unknown when the highest titer were the same with two or more serogroups.

\section{RESULTS}

During the period 1969-1997, a total of 9,335 cases were recorded. A peak was observed in 1991 and 1996 with 821 and 910 cases, respectively (Fig. 1). The highest rainfall average was in 1976, 1983, 1991 and 1996 (Fig. 2). The seasonal summer distribution was evident in all years, with the peak months being January to April (Fig. 3).

The mean annual incidence rate was 0.53 per 100,000 population. The Figure 4 shows the cases of leptospirosis and incidence rate. The highest incidence rates were observed in 1991 and 1996 with 1.13 and 1.05, respectively. The incidence rate was calculated since 1970 because there is no information about population in 1969. Although leptospirosis occurred in persons of all ages, middle-aged adults were most frequently 


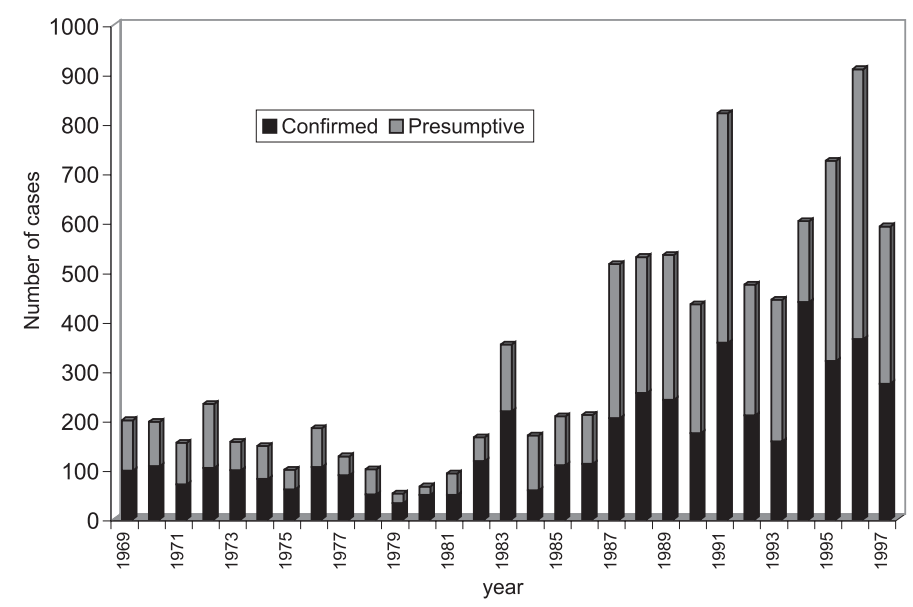

Fig. 1 - Distribution of confirmed and presumptive cases by each year (São Paulo, 19691997).

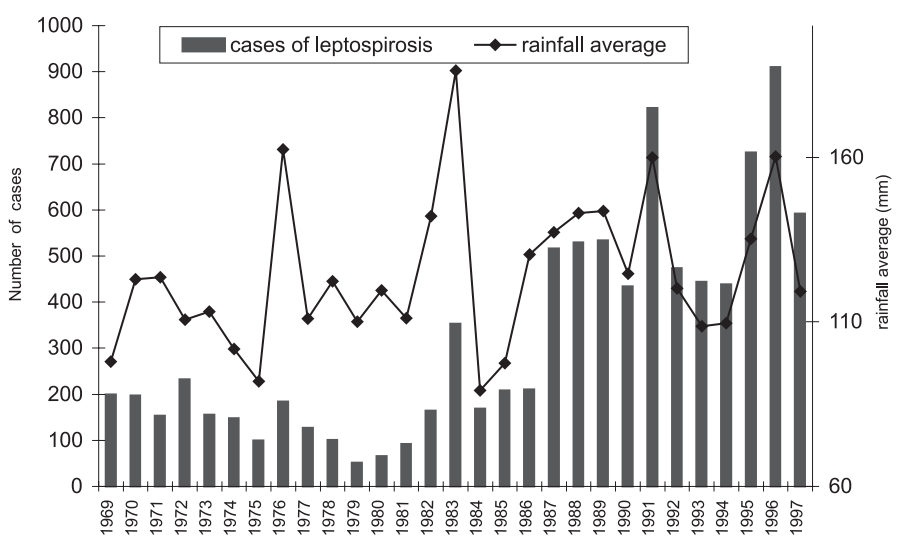

Fig. 2 - Total of cases of leptospirosis and rainfall average

infected: $32.40 \%$ of the cases were in adults from 20 to 39 years of age, mostly males $(87.0 \%)$ with an overall ratio of males to females of $6.7: 1$ (Table 1).

Among the 9,335 cases of leptospirosis, 4,346 (46.56\%) were considered serologically confirmed cases and 4,989 (53.44\%) presumptive cases. The Figure 1 shows the distribution of confirmed and presumptive cases by each year. Cross-agglutination with at least two serogroups occurred in 1,539 cases. Icterohaemorrhagiae was the predominant serogroup ( 5,115 cases, $54.80 \%)$, followed by Autumnalis (521 cases, $5.58 \%$ ) and Canicola (400 cases, $4.29 \%$ ) (Table 2). There was no difference in the serogroups neither among the years nor in the cities of the state of São Paulo.

Leptospirosis is spread throughout the whole territory studied. However, $68.43 \%$ of reported cases was acquired in the greater São Paulo area (capital of the state of São Paulo and 36 nearby municipalities) with 6,388 cases and $31.57 \%$ was from the other cities within the state of São Paulo.

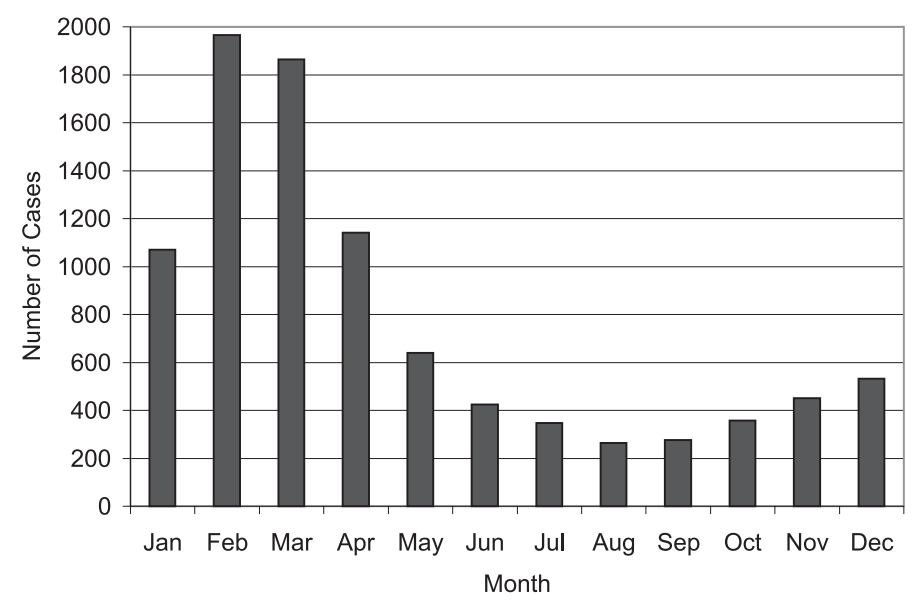

Fig. 3 - Total of confirmed and presumptive cases of leptospirosis in humans by month (São Paulo, 1969-1997).

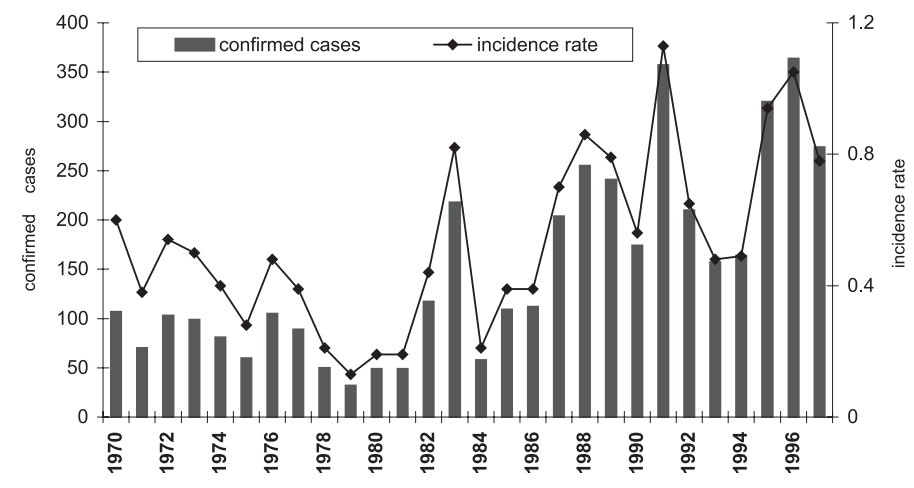

Fig. 4 - Total of cases of leptospirosis and incidence rate (confirmed cases/100,000 population).

Table 1

Cases of human leptospirosis by age and sex distribution (São Paulo, 1969-1997)

\begin{tabular}{lccrc}
\hline \multirow{2}{*}{$\begin{array}{l}\text { Age range } \\
\text { (years) }\end{array}$} & Male & Female & \multicolumn{2}{c}{ Total $(\%)$} \\
\cline { 2 - 5 } $0-9$ & 144 & 52 & 196 & $(2.1)$ \\
$10-19$ & 1,003 & 123 & 1,126 & $(12.1)$ \\
$20-29$ & 1,346 & 182 & 1,528 & $(16.4)$ \\
$30-39$ & 1,306 & 190 & 1,496 & $(16.0)$ \\
$40-49$ & 844 & 136 & 980 & $(10.5)$ \\
$50-59$ & 428 & 89 & 517 & $(5.5)$ \\
$>60$ & 237 & 62 & 299 & $(3.2)$ \\
Unknown & 2,813 & 380 & 3,193 & $(34.2)$ \\
\hline Total $(\%)$ & $8,121(87.0)$ & $1,214(13.0)$ & 9,335 & $(100.0)$ \\
\hline
\end{tabular}


Table 2

Distribution of serogroups diagnosed by MAT (São Paulo, 1969-1997)

\begin{tabular}{ll}
\hline Serogroups & No. of cases $(\%)$ \\
\hline Unknown * & $1,539(16.49)$ \\
Australis & $128(1.37)$ \\
Autumnalis & $521(5.58)$ \\
Ballum & $175(1.88)$ \\
Bataviae & $199(2.13)$ \\
Canicola & $400(4.29)$ \\
Celledoni & $4(0.04)$ \\
Cynopteri & $214(2.29)$ \\
Djasiman & $28(0.30)$ \\
Grippotyphosa & $286(3.06)$ \\
Hebdomadis & $118(1.26)$ \\
Icterohaemorrhagiae & $5,115(54.80)$ \\
Javanica & $58(0.62)$ \\
Panama & $215(2.30)$ \\
Pomona & $98(1.05)$ \\
Pyrogenes & $48(0.51)$ \\
Sejroe & $170(1.82)$ \\
Shermani & $9(0.10)$ \\
Tarassovi & $10(0.11)$ \\
\hline
\end{tabular}

* Cross-agglutination with at least two serogroups

\section{DISCUSSION}

Over a period of twenty-nine years, 9,335 cases for which laboratory data were available were selected in a retrospective study to provide a picture of leptospirosis in the state of São Paulo, Brazil. After 1997 the diagnosis of leptospirosis was also conducted by other two laboratories (cases from some other cities within the state of São Paulo and from the coastal area).

The weather in the state is tropical and a rainfall occurs during the hot season from December to April. These climatic conditions explain the evolution of the incidence of leptospirosis during the year characterized by a clear seasonal pattern with an increase in the months from January through April (Fig. 3). Our results are consistent with those of CORREA $\hat{A}^{1}$ who reported the cases of leptospirosis in the state of São Paulo until 1968.

As in all tropical countries where the population is exposed to leptospirosis, mainly in the rainy period, it was difficult to identify highrisk groups. Although leptospirosis has been regarded as an occupational or recreational disease in other countries, in Brazil the disease is mainly acquired by the contaminated water in a rainy period with epidemiologic characteristics also related to the socioeconomic context ${ }^{4}$. The majority of the cases occurred in males from 20-39 years of age, although the age of many cases among 1972 and 1984 were unknown (Table 1). Although 1976 and 1983 had and average rainfall of 162.4 and 183.3, respectively, the highest incidence rates were in 1991 and 1996 (Fig. 2 and 4). This is probably due to an improvement in methods of diagnosis, very possibly to the higher incidence of the disease which is no longer of exceptional occurrence, the interest of the medical staff or, alternatively, because in 1983 the leptospirosis was designated a notifiable illness. In addition, an increase in inadequate housing conditions, with the creation of extensive areas of high population density lacking basic sanitation accompany the development of the major cities in Brazil. We observed that the largest number of cases was reported 2-3 weeks after the heavy rainfall suggesting that contact with flood water contaminated by rat urine was the probable mode of transmission. The results of this study provided unequivocal evidence of the widespread distribution of leptospirosis in human populations in the state of São Paulo.

Distribution of serogroups shows that Icterohaemorrhagiae is highly predominating in the state of São Paulo in all years. This is partly due to the severe form of the disease that requires hospitalization or more investigations. This is confirmed by isolates identified by crossagglutination absorption test in human cases: 14 of the 18 isolates were identified as Icterohaemorrhagiae, 2 as Canicola, 1 as Ballum and 1 as Pomona. All serogroup Icterohaemorrhagiae isolates were identified to be serovar copenhageni ${ }^{7}$. Taking into account that the anicteric form occurring in $85-90 \%$ of the cases ${ }^{3}$ and frequently is misdiagnosed, the 9,335 cases from this period do not fully reflect the incidence of the disease in the state of São Paulo. Leptospirosis is undoubtedly underdiagnosed in Brazil because of the low index of suspicion among clinicians and the difficulty of laboratory diagnosis mainly with mild and nonspecific symptoms. In addition, the results of numerous studies indicate that leptospirosis must always be considered in the differential diagnosis of suspected viral infections of the central nervous system ${ }^{6,8}$. Also, the specific antibody response of the host can be inhibited by early antibiotic treatment and is difficult to evaluate in areas where leptospirosis is endemic and reinfection can occur.

The frequency of cases reported by the Adolfo Lutz Institute has been steadily increasing. Serologic tests are frequently requested by physicians to confirm the diagnosis of leptospirosis and they should become familiar with the signals and symptoms of the disease and with the limitations of the currently available serologic tests.

Ultimately, continued surveillance for leptospirosis is needed for determining the extent of the disease and this should increase our understanding of the evolving epidemiology of leptospirosis and facilitate the development and implementation of effective control measures.

\section{RESUMO}

\section{Leptospirose humana: estudo sorológico de 29 anos em São Paulo, Brasil}

Estudo retrospectivo com 9.335 casos de leptospirose humana no Estado de São Paulo, Brasil, diagnosticados entre 1969 e 1997 mostrou que a doença é endêmica no estado. Adultos com idade entre 20-39 anos foram os mais infectados $(32,40 \%)$ sendo $87,0 \%$ dos casos do sexo masculino. A incidência anual média foi de 0,53 por uma população de 100.000. Casos ocorreram principalmente em janeiro a abril de cada ano. O maior número de casos foi observado em 1991 e 1996 com média pluviométrica de 159,9 e 160,3, respectivamente. Estes dados enfatizam a importância da leptospirose na saúde pública no Estado de São Paulo, Brasil.

\section{ACKNOWLEDGEMENTS}

We are grateful to Sandra Regina da Silva, Leptospirosis Laboratory, 

2003.

Adolfo Lutz Institute, for the assistance of reviewing the data and to all researchers for contribution in the study. We also thank Sergio Torre Salum, Frederico Luiz Furnari and the staff of Instituto de Astronomia, Geofísica e Ciências Atmosféricas, University of São Paulo for the permission of using their databases.

\section{REFERENCES}

1. CORRÊA, M.O.A. - Leptospiroses em São Paulo. Rev. Inst. Adolfo Lutz, 29/30: 29-37, $1969 / 70$.

2. FAINE, S.; ADLER, B.; BOLIN, C. \& PEROLAT, P. - Leptospira and leptospirosis. 2. ed. Melbourne, MediSci, 1999.

3. FEIGIN, R.D. \& ANDERSON, D.C. - Human leptospirosis. CRC Crit. Rev. clin. Lab. Sci., 5: 413-467, 1975.

4. KO, A.I.; REIS, M.G.; DOURADO, C.M.R.; JOHNSON Jr., W.D. \& RILEY, L.W. Urban epidemic of severe leptospirosis in Brazil. Lancet, 354: 820-825, 1999.
5. ROMERO, E.C.; BERNARDO, C.C.M.; BARRETO, I.M.Q. \& YASUDA, P.H. Situation of human leptospirosis in São Paulo, Brazil. A thirteen years study. In: CONGRESO ARGENTINO DE MICROBIOLOGÍA, 8. Buenos Aires, 1998. Abstract L-6. p. 346.

6. ROMERO, E.C.; BILLERBECK, A.E.; LANDO, V.S et al. - Detection of leptospira DNA in patients with aseptic meningitis by PCR. J. clin. Microbiol., 36: 14531455, 1998.

7. SAKATA, E.E.; YASUDA, P.H.; ROMERO E.C.; SILVA, M.V. \& LOMAR, A.V. Sorovares de Leptospira interrogans isolados de casos de leptospirose humana em São Paulo, Brasil. Rev. Inst. Med. trop. S. Paulo, 34: 217-221,1992.

8. SILVA, H.R; TANAJURA, G.M.; TAVARES-NETO, J. et al. - Aseptic meningitis syndrome due to enterovirus and Leptospira sp in children of Salvador, Bahia. Rev. Soc. bras. Med. trop., 35: 159-165, 2002.

Received: 28 January 2003

Accepted: 10 October 2003 